\title{
When the Floods Came
}

Water, rock, and mud descended on Kedarnath twice, first in the evening of June 16,2013 , and then in the morning around seven on June 17, 2013. Those hours are in fundamental ways beyond discursive reach. But we can try to gather fragments, as have dozens of video documentaries, hundreds of journalist accounts, and thousands of Facebook posts. In a fragmentary way, it is possible to say that Kedarnath remained, during and after the flooding, a place that resisted human control and a place marked by a relatively high level of shared experience across diverse social, economic, and cultural subjectivities. It remained a zone of transition to the beyond-human, a vanishing point relative to human frameworks of understanding and control. It remained a place characterized by the enmeshing of the divine and the natural. The floods came as a surprise and a rupture, but also, given their Himalayan location, they were not a surprise and they were not a rupture.

I embark on the description of this event with the concept of "border situation" in mind as it is discussed by anthropologist Michael Jackson in his work The Palm at the End of the Mind. Jackson (2009, xii), as part of a broader engagement with the question of the putative cultural universality of something called "religious experience," found himself focusing on "critical situations in life where we come up against the limits of language, the limits of our strength, the limits of our knowledge, yet are sometimes thrown open to new ways of understanding our being-in-the-world, news ways of connecting with others." He was drawn to the term situation and its use in compounds like limit situation (from Karl Jaspers) and frontier situation (from Theodor Adorno) because the concept of situation is an "existential" concept that engages experiences of being-in-the-world in a way 
that does not reduce those experiences to either "political economy" or "religious belief or doctrine" (Jackson 2009, xii). I am not focused in this work on arguing for or against the specialness of religious experience. However, being in Kedarnath in the best of times has constituted, I think, the beginnings of a border situation for many in which a combination of multiple elements (some of which are understood to be "divine") of the situation exert ontological weight. And this, awfully, would have been even more the case during the floods. In this chapter, I treat the first days and weeks of the disaster (Hindi: apda) as a sort of border situation. My primary goal in this chapter is not to critically assess the relief and rescue measures undertaken by the state government, the national government, and other groups, though a critique is absolutely warranted. Nor is it to offer, as Michelle Gamburd $(2012,2)$ does regarding the impact of the 2004 tsunami in Sri Lanka, the first stage of an argument about the "social consequences of natural hazards and the cultural processes at work in humanitarian relief efforts" and to analyze closely the nature of relief efforts and funding in the aftermath of the tsunami. My primary goal is to attend to the feeling of the situation.

Among scholars of disaster, it is conventional wisdom to note that, while disasters are often experienced and pictured as catastrophic and surprising events of short temporal duration, close analysis often reveals that the conditions that came together to produce the experience of what is often called a "natural disaster" sprang from a deeper and broader set of causes such as (often willful) human ignorance or selfish, unjust myopia about safe, long-term strategies of residence and anthropogenic landscape change in a specific location, and that consequently the disaster might be better termed an unnatural disaster, or a disaster with an "unnatural history" (Steinberg 2000). Such events are properly understood in the "longue durée." Anthony Oliver-Smith (1999a, 75), for example, in his analysis of a terribly destructive earthquake in Peru, wrote that "the destruction and misery in Peru in 1970 and after were as much a product of that nation's historic underdevelopment as they were of the earthquake" and that this underdevelopment was tied to Peru's colonial past. The human vulnerability that is on terrible display during these events is, in many ways, a vulnerability that has arisen out of a specific set of longer-term eco-social conditions. But this way of understanding disasters does not mean that we should not attend to the events themselves and how they were experienced at the time. Therefore, in this chapter (complemented by the longerterm analysis offered in the next chapter) my goal is to attempt (and of course necessarily fail) to give a sense, from a distance, of how the places of Kedarnath and the Kedarnath valley may have "felt" at this time and to contextualize what they felt like at this time relative to the broader life of the place in a way that captures something that people who survived would recognize. I was not in Kedarnath in June of 2013, though had travel plans turned out differently I might have been. I therefore drew on media accounts, phone and e-mail conversations, eyewitness 
accounts on Facebook, and government reports in assembling what follows. In the next chapter the analytic view again widens.

Imagine that you were a visitor to Kedarnath. You were at approximately 3,500 meters in the Himalaya and a cold rain had been falling continuously for days. You had just completed a demanding journey. You probably had come in a small bus or car from somewhere between Rudraprayag or Guptkashi the day before, passing most of the day (or night) on a narrow mountain road with a great deal of traffic. The day before that, you had come south from Rishikesh or Srinagar or east from near Uttarkashi. The road had taken you only as far as Gaurikund. The mostly paved path from Gaurikund had been muddy and slippery, the rain partially masking the smell of horse and pony urine. If you rode, as the majority of visitors had begun to do in recent years, then your thighs hurt and there were many moments of anxiety that the creature would fall into the ravine and thence into the Mandakini River. Many people could not mount or dismount from the horse without assistance. If you were a woman this might have meant that you needed to accept the somewhat intimate help of a strange man. If you came on foot then you were mentally tired from avoiding being pushed over by ponies or visitors being carried in palanquins. You would have ascended over 1,500 meters in the last day or two. You might feel sleepy or dizzy or struck with headache. You might be so overcome at finding yourself in Kedarnath and so focused on reaching the temple that you were unaware of any of the environmental factors described in this paragraph. If you flew over all of this and arrived by helicopter it meant that you did not know when you would be able to leave-it was raining so hard that helicopter service had been stopped.

You found yourself amid a press of people because it was the high season. Approximately ten thousand visitors and hundreds of temporary residents were together in an area of approximately two American city blocks square. Many rooms were going for over one thousand rupees per night, and it was difficult to find a place to stay without prearrangement. You were surrounded by families with schoolchildren on vacation. If you were in Kedarnath or the upper Kedarnath valley and you were not a visitor, then this time would have been busy, challenging, and draining. For residents of the Kedarnath valley and other Uttarakhandis who made their living from the pilgrimage tourism industry, as well as porters (often from Nepal or Uttar Pradesh) and sweepers (from Uttar Pradesh) who came to the Kedarnath corridor solely for employment, this month and a half provided most of the income for the year. That meant that people had been constantly on the go for over a month in a high-altitude, high-stress environment with a great deal of money at stake.

Social tension was part of the weather in Kedarnath in mid-June of 2013. The porters were on strike, protesting the growing amount of helicopter service to Kedarnath and the special privileges accorded its passengers. In mid-June of 2013 
this meant that many visitors to Kedarnath found their existing plans suddenly interrupted by the unavailability of horses and ponies. If you were only just arriving in Kedarnath at some point in the morning then quite possibly the line would have been too long for you to take darshan in the inner sanctum on that day. So Kedarnath was exceptionally full: of people, of shakti, of rain, of tension. Many local youths were also visiting Kedarnath either for pleasure or for shortterm work because they had just finished their semester at intercollege.

\section{THE FLOOD EVENTS}

It had been raining very heavily since the day before. The monsoon came to the area several days early. Monsoon rains crossed Uttar Pradesh and were in the mountains in a single day. Monsoon weather coming from the Arabian Sea in the west and the Bay of Bengal in the east suddenly bracketed Uttarakhand. In a very short period of time, Kedarnath arguably received "more than half the rainfall Delhi receives in an entire year" (Mihir and Irani 2013). Behind Kedarnath by this time the rains had already caused a great deal of river gulley erosion. Accumulated sediment was making it difficult for the extra water to flow naturally, and instead it was building up (Dobhal et al. 2013, 173-74).

It is necessary to understand how Kedarnath is situated geologically. It is located on the "outwash plain" of several glaciers that lie to the immediate north of the site (Dobhal et al. 2013, 173) and rests on somewhat unstable layers of rock, dirt, and mud left over from previous glacial movements. The Mandakini and Saraswati Rivers flow down through glacial moraine after emerging from the glaciers. The main course of the Mandakini flows to the west of Kedarnath. The main course of the Saraswati used to flow to the east of Kedarnath but in recent years had been diverted by barricades and was now flowing southwest into the Mandakini, joining it just above and behind Kedarnath. That meant that directly behind and rising above Kedarnath at steep pitch were small mountains of ice and rock out of which two rivers were flowing. Each of these rivers had a small network of smaller gullies that would not fill with water unless the river was in spate. This entire area had been filling up with water all day because of the massive rainfall.

As the situation unfolded, it quickly became apparent that Kedarnath, and Uttarakhand more generally, were undergoing extreme flooding. I will use part of an account written by Pyoosh Rautela $(2013,45)$, director of Uttarakhand's Disaster Mitigation and Management Centre, to structure the discussion of the flooding and its immediate aftermath:

Most evidences on ground having been obliterated by flood it is important to look for circumstantial evidences in the narration of the survivors of the deluge so as to reconstruct the sequence of events. As narrated by the survivors of the disaster; i) there were incessant rains in the area between 14 and 17 June, 2013, ii) rainfall 
on 16 and 17 June, 2013 was particularly heavy, iii) tragedy struck Kedarnath on the night of 16 June, 2013 and in the morning hours of 17 June, 2013, iv) hitherto abandoned eastern channel of Mandakini at Kedarnath became active in the evening hours of 16 June, 2013, v) flooding in Kedarnath was not that devastating on 16 June, 2013 though it washed off the pedestrian bridges over Mandakini connecting Kedarnath to Rambara and turning Kedarnath into an Island, vi) on 16 June, 2013 flood waters washed off Sanatan Dharm Sabha guest house, Shankaracharya Samadhi and a few other structures in the vicinity of the temple together with a few persons, vii) floodwaters of Mandakini did not affect the Kedarnath temple premises on 16 June, 2013, viii) after the flood event, despite heavy rains, most persons in Kedarnath assembled in the temple premises and engaged in prayers.

At around 5:15 p.m. things started to come to a head (Dobhal et al. 2013, 173). The volume of rain and glacial runoff caused these existing gullies to erode. Debris from the gulley sides, combined with the presence of the barricade, meant that much of this water began to pool above Kedarnath rather than flow down the valley. When this pool built to a sufficient volume it surged to Kedarnath and "simultaneously picked [up a] huge amount of loose sediment en route" (Dobhal et al. 2013, 174). This surge of water and debris washed away the structures in the northwestern part of Kedarnath and, much of its force undiminished, continued downstream. Different eyewitness accounts place this surge within a two-hour window, but most agree that it happened while shringar arati was occurring. The temple became a gathering place for much of the night. Many people stayed there until early morning for safety, comfort, and prayer. A renunciant who survived the floods told me that he spent that night in his customary location just to the east of the temple listening to the screams and cries of those in the temple, a memory that (combined with the trauma of surviving the two flood events) drove him out of his mind for months. There were now two rivers flowing in spate, one on either side of Kedarnath. And the bridge across the Mandakini connecting Kedarnath to the path down to Gaurikund was gone. This surge of mud and water continued downstream and erased the village of Rambara.

I came across a literary description of this time in Rambara in a book entitled Apda Ka Kafan (Disaster's Shroud; Pāṇdey 2014, 4-5). The title of the section was "Trahi Mam." This phrase is part of the mantra, discussed in chapter 4, that is recited along with the ghee massage in the inner sanctum of the Kedarnath temple:

I am a wicked person [Sanskrit: papa], I am one whose actions generate wickedness, my inner being [Sanskrit: atma] is full of wickedness, I am one from whom wickedness arises. Save me [Sansrkti: trahi mam], lord of Parvati! O Shiva, you destroy all papa.

The few who survived the situation in Rambara managed to quickly climb the steep sides of the valley amid rushing water, mud, and landslides. The majority of those in Rambara did not survive. The lower half of the river valley between Kedarnath and Gaurikund, and continuing down to just north of Sonprayag, 
is quite deep and narrow. This would have focused the force of the surge as it rounded the corner into Gaurikund. It tore away three-quarters of Gaurikund and roared into the flat and open bazaar of Sonprayag, which had been built that way to accommodate the hundreds of buses, cars, and jeeps that pass through during the high season, and swept vehicles and houses on the east (river) side of the village into the churning waters. It weakened the hillside and caused landslides all the way down the Kedar valley. It submerged a recent hydroelectric project built at Kund, where the road forks, with one road leading to Guptkashi and the other road to Ukhimath and, via Chopta, Badrinath.

When I write these things about Rambara, people and scenes flash in front of my mind's eye. Many of the shopkeepers in Rambara were from the Ukhimath side of the valley, and I felt a personal connection with them. In my own foreign way, I am more connected to the Ukhimath side because that is where I lived during the off-season. I once spent three hours warming up in a cigarette shop no bigger than the width of two people because the proprietor had seen me many several times in his village of Kimana, one of the villages that make up the village cluster known as Ukhimath. Bhupendra's father owned a shop in Rambara that he rented out. Bhupendra, with whom I lived and worked in Kedarnath for a season, was also from Kimana, so this brings me to what happened to him. The first flood event took him in his room on the northwestern side of Kedarnath, I was told later. $\mathrm{He}$ was working for one of the private helicopter companies in Kedarnath and was off duty at the time. I suspect he would have been cooking dinner, as he taught me to do. I am sure that if he had time he tried to save others around him. Also lost at this time were Mahant Chandragiri and his langar, and Bharat Sevashram Sangha. Many sadhus built temporary shelters along the path that went from near the free food kitchen northeast down to the temple. During high season the queue for darshan would stretch around the corner, and the sadhus would be able to interact with and receive donations from yatris who were waiting in line. Most of these sitting Shivas would not have had time to elude the waters.

Early in the morning of June 17, most people thought that they were past the worst and that the worst had been a recognizable disastrous event: flooding.

x) Major devastation took place in Kedarnath in the morning hours of 17 June, 2013, xi) Chorabari Tal was intact on 16 June, 2013, xii) Rambara and Gaurikund were devastated in the night of 16 June, 2013, xiii) breach of Chorabari Tal took place around $0700 \mathrm{hrs}$ on 17 June, 2013 and xiv) floodwaters of Mandakini ravaged Rambara, Gaurikund and Sonprayag again in the morning hours of 17 June, 2013. (P. Rautela 2013, 45)

But what happened at around seven that morning was something different. Intense rain had continued to fall, snowmelt had continued, and the volume of water in the lake known locally as Chorabari Tal (and more famously as Gandhi Sarovar) continued to rise. Chorabari Tal is a famous destination for those who 
arrive in Kedarnath with energy to spare who wish to take in the "natural beauty" of the Himalaya. It is a lake that is filled by glacial runoff and may be mostly empty or quite full depending on the time of year. Normally, excess water in the lake would have seeped out and down through the network of holes and gullies in the moraine barrier that constituted a major portion of the boundary of the lake and part of the debris layer on top of the snout of the Chorabari glacier. But all of the rain and previous erosion and accumulation of debris meant that there was no place for the massively accumulating volume of water to go. It broke. “ " was the sound it made. A wave of water, mud, rock, and debris rushed down from the lake to which I had once walked with Bhupendra (whom people often called Bhupi for short) and where we had once written "Luke and Bhupi" on a rock. Many people have described the wave as more than ten feet tall. Two scientists from the Wadia Institute of Himalayan Geology had been at their monitoring station near Chorabari Tal and saw it happen. ${ }^{2}$

People had a split second to make a decision about what to do. Many who survived scrambled up the hillside toward the Bhukund Bhairavnath shrine. Others found a roof that, for the fortunate, did not later collapse. Some took refuge in the temple. When I visited Kedarnath and the Kedar valley I heard many accounts in which people had saved someone (a child, a relative, a stranger) from the flowing mud-rock but had been swept away themselves. A Guptkashi man in Kedarnath at the time could say only that it was "beyond imagination" (Hindi: kalpana ke bahar). When I see people talk about it in person or in television interviews I see often see the same facial moment-a quick tightening of the face, a ripple of intense emotion, and then diminished affect.

I know what I know about this event in different ways. I spoke with some people on the phone in the weeks following the floods. I read accounts online and watched interviews on YouTube, often with people whom I recognized from my fieldwork. When I managed to speak with survivors in person for the first time a year after the event, I often could not bring myself to ask people to narrate what they experienced. I did not want to ask them to go back to that moment. I remember what a friend of mine said to me after he told me on the phone that he had been in Kedarnath and survived. He said, "I saw Shiva's tandava." I said, "I cannot imagine it." His response was something to the effect of "Good. That is right. You can't." Now, as I write, I cannot remember the exact words. I did not take notes because I was not thinking about notes. But I remember the tone, the edge in his voice. So the data that I have on these moments are what particular people wanted to tell me and not what I sought out or invited. I have heard only a dozen or so granular accounts in person.

I struggle with how to write about all of this from the infrastructure-rich environment of Wisconsin. The natural impulse, both for journalists and for scholars who value thick description, is to present first-person accounts, to pay attention to what this moment was like for particular people who were there when 
it happened. I am not so sure that this is what I can or should do. First, I do not want to beguile the reader with gripping, sensational accounts of disaster survival. Second, given that I was not there and only journeyed to Uttarakhand a year later, I do not want to write in such a way that the text persuasively collapses the insurmountable distance between what I write and what happened. I am distant from what happened. I am insulated. That is part of my position. Third, from the necessary distance at which I am writing, it seems to me that narration risks imposing chronology and structure on these minutes that maybe was not there. This assertion maps to one of my broader claims about the place of Kedarnath at other times, that it is a place where stories and words run out. So instead I am trying to write in a spare way that both suggests how things felt and does not pretend to know or even to offer the clearest possible picture. At the same time, I know that as I write I am lending scholarly weight to public perceptions of what happened at this time.

There are several digital animations on YouTube that include a computergenerated animation of the two flood events in Kedarnath. I have watched such animations several times, and though the shape of the computer-generated waves has a regularity that does not match the terrain it is nonetheless chilling. I had, and have, difficulty watching such animations. If you were in Kedarnath, then for several unrecoverable minutes this wave-event was all that was happening. There was a shattering sound. Then the mud-rock-wave began to fall down the slope. There was a moment to realize what was happening, but there was so much sound that it was without sound. You had to get out of the way. You had to help other people get out of the way. Everything narrowed. You either moved or did not. It was like this:

Almost every account of this event that I heard a year later when I visited included some version of the Hindi verb bhagna, to flee. There were several ways to survive. All of them involved making a quick decision about where to run. The first was to seek high ground. If you were on the eastern side of Kedarnath, this meant heading away from the flow of mud and water toward the helipad or up toward the Bhukund Bhairavnath shrine and beyond. If you were caught on the path to Kedarnath, this meant scrambling up toward Vasuki Tal or above Garud Chatti and hoping the steep mountainside did not collapse. The path was collapsing and falling into the river. It was difficult to survive getting caught in the mud. When I visited the Kedarnath valley in 2014, an acquaintance of mine, with almost no change of expression, told me that he had been in Kedarnath at that time and had managed to save only one of his children from the mud. Reports of this sort were common, as were accounts in which the successful rescuer became the victim. Some strangers and loved ones saved each other in that moment of and others could not.

Another impulse was to take shelter in the temple. The numbers conflict, but at least dozens of people went back into the temple. Shielded by a massive boulder, 
later termed a "divine rock" (Hindi: divya shila), and by its own solid construction, the temple itself held firm but filled up with mud and water. Some people also found themselves on the roofs or upper stories of buildings that did not collapse. If you made it up to the plateau behind the Bhukund Bhairavnath shrine, you would have gained enough distance to feel, temporarily, out of the situation. If you were in the temple, or on a roof, then you were marooned inside what was happening. And if you were in the temple, it is difficult to talk about later. All along the path down Gaurikund and beyond, people caught near rising mud and water sought high ground, and most (except in Rambara and Gaurikund) were successful. However, surviving the immediate event did not mean surviving the disaster.

Many people, once immediately out of harm's way, found a place to wait, and from that point it was a struggle against hunger and cold, often for several days, until relief came. This waiting took several forms. In the dark coldness of the temple it meant clinging for hours to something near the ceiling of the temple, like a bell, to keep one's head out of the muddy water and be one of those who would survive until the waters went down. This meant clinging to life for hours (and in some cases days) amid the bodies of the recently dead and dying (Press Trust of India 2013i; Rediff 2014). ${ }^{3}$ Hridayesh Joshi (2014; trans., 2016), one of the first journalists who reached Kedarnath after the floods, offers a vivid, passionate, important account of this moment.

Visitors who had fled up the sides of the Mandakini River valley to the east or to the west then found themselves fighting hunger, cold, and trauma in a Himalayan environment for which they probably were not prepared under normal circumstances upon arrival in Kedarnath. The weather in the Uttarakhand Himalaya, even in summer, is different enough that in my experience most visitors (unless they are from a neighboring mountain-state like Himachal Pradesh or a country such as Nepal) are often not prepared because they do not think it necessary to purchase gear that they will need for less than twenty-four hours. When in Kedarnath I often felt, to my embarrassment, that without my costly warm and waterproof clothing and sleeping bag I would have found it impossible to live there. The same layers I wear in a Wisconsin winter were barely enough to be comfortable at night in Kedarnath in May 2014. Living and breathing at 3,500 meters also demands a massive caloric load. People who made it out of the floods had none of these things and simply had to wait for helicopters with soldiers to come because helicopters were the only possible means of delivering relief.

Others, mostly but not only locals, became convinced that it was not practical to await rescue and that it made more sense to walk to safety using high mountain paths that led into adjoining valley systems: if trapped on the western side of the Mandakini they went up and to the southwest beyond Vasuki Tal and then down to the villages of Tosi and then Triyugi Narayan, and if trapped on the eastern side of the Mandakini they went up past Bhukund Bhairavnath and then across 
and down to the southeast and eventually into the northern ends of the Kalimath valley system. This also took several days, and the villages deep in the Kalimath valley and above Triyugi Narayan saw groups of cold, starving survivors stumble in days later and immediately start looking for ways to let their families know they were alive. These survivors had made their way through cold jungles scattered with the bodies of those who had been too hungry, dehydrated, sick, or old to successfully walk to safety (Basu 2013, 90; HT Correspondents 2013; Zee Media Bureau and Press Trust of India 2013).

Those who did not find their way to a functional village with food and warmth also had to wait for several days before they were either picked up or in many cases given the short-term supplies they needed to stay alive. The weather was so bad that helicopters had difficulty flying up into the northern part of the Kedarnath valley. On June 21 a helicopter crashed during a rescue attempt. I do not know if it was the same helicopter, but I saw the remains of a helicopter between Gaurikund and Jungle Chatti on the path to Kedarnath in May 2014. Those whom helicopters did successfully pick up were first taken to staging stations farther south in the Kedarnath valley like Fata or Guptkashi or other sites near Rudraprayag like Agastmuni and Gauchar that had been high enough or far enough from a river to have come through the flooding with minimal damage and that had helipads. Eventually the survivors moved from these places to Dehra Dun, where they, along with the other tens of thousands of evacuees, stayed until circumstances and resources permitted them to make their way home (Upadhyay 2013b). By this time survivor accounts were part of the public sphere across Uttarakhand, across India, and across the world (H. Kumar 2013a; Press Trust of India 2013d). Here is another summary, again from Piyoosh Rautela $(2013,47)$ :

The sequence of events in the Mandakini valley took everyone by surprise and none really got chance of raising alarm of any sort. Attempts were however made to communicate the news of flooding over high frequency police radio set but the seriousness of the incidence could not be assessed from hurriedly communicated incomplete message. All communication with Kedarnath valley was snapped in the late evening of 16 June 2013. Adverse weather and terrain conditions did not provide opportunity of resorting to alternative probes. The outside world as also the local administration therefore remained unaware of the events in Mandakini valley till the afternoon of 17 June, 2013.

Aerial rescue operations could therefore be initiated in the morning of 18 June 2013. Ground search and rescue operations were hampered by washing off of the pedestrian track at many places between Gaurikund and Rambara and could start on 19 June, 2013. Terrain conditions made it difficult even to airdrop food and water at many locations where people were stranded in large numbers. Challenges faced even in aerial rescue operation can well be understood from the fact that three choppers got crashed during rescue operations in Mandakini valley.

Massive ground and aerial search and rescue operations were however organized jointly by National Disaster Response Force (NDRF), Indo-Tibetan Border Police 
(ITBP), Indian Air Force (IAF), Indian Army and Civil Administration to evacuate the survivors. Temporary helipads were quickly prepared and activated for evacuating persons stranded between Gaurikund and Rambara. In all around 6,817 persons were evacuated by air and another 18,183 by foot track. Despite best efforts evacuation could only be completed on 23 June, 2013.

For almost twenty-four hours no one knew exactly what had happened in Kedarnath, though the flood surge had obviously originated there. Then, despite full knowledge of what had happened, rescue efforts and helicopter reconnaissance could not begin until the next morning because of the combination of altitude, weather, and darkness. For almost a full day, there was simply no way to reach Kedarnath. The instability of the terrain and the continued bad weather made it difficult for up to two days even to deliver supplies to survivors between Gaurikund and Rambara, and attempts resulted in helicopter crashes. During those first days bodies were coming down the river and groups of survivors were coming out of the jungles and finding their way to villages in the upper Kedarnath valley and giving preliminary eyewitness accounts to media, to government agencies, and to local families. It was known that survivors of the floods were trapped and needed help, but the knowledge could not immediately be acted upon. But what this meant was that people struggling to survive on the ground occasionally saw helicopters but did not necessarily receive help from the helicopters they were able to see. The difficult location, combined with a profound lag in response time by the state government, meant that it took several days for the full impact of state and central government resources to be felt. In those early days, as Hridayesh Joshi (2016) has poignantly described, the gap was filled in part by commercial helicopter pilots and volunteers. For several days there was something very close to a silence, a gap. It took several days for those stranded in Kedarnath to leave the site by one way or another. It also took at least several days for anyone outside a disasterstruck location to obtain reliable news about what was going on. And then, like something you see first but cannot hear until moments later, trauma and confusion began to ripple out from those first moments. And the environment was not finished setting the terms. More bad weather was expected on the twenty-third, which meant that survivors needed to be evacuated before then (Gupta and Sunderarajan 2013).

\section{THE BEGINNINGS OF THE AFTERMATH}

By June 19, different threads of the situation, to use Jackson's term, began to ripple outward and separate out into different stories. There were rescue efforts, and the plight of survivors continued to unfold on the ground in the Kedarnath valley and in Uttarakhand more broadly. Rescues were effected by massive combined military civil rescue operations code-named Surya Hope and Rahat (India Today Agencies 2013; Daily Bhaskar Staff 2013). These involved the efforts of local civilians, police, 
the Indian Army, the Indo-Tibetan Border Police, the Border Roads Organisation, the National Disaster Response Force, the Indian Air Force-according to one news report the combined efforts of over eight thousand rescuers and fifty-five helicopters tasked with the rescue and evacuation of well over fifty thousand people (Gupta and Sunderarajan 2013). In these initial stages these prestigious, powerful resources of the central government took primary place, and even these resources were coming up against the limits of the situation-rescue helicopters trying to get to Kedarnath crashed during this time (Peer 2013).

At the same time, survivors were making their way out of the hills, as I mentioned earlier. Relatives of visitors to Uttarakhand who were missing had arrived in Dehra Dun and were showing pictures of missing family members to rescue workers coming down from the mountains. Growing numbers of visitors to Uttarakhand who had been rescued from immediate peril were arriving in Dehra Dun, sharing their stories, and on occasion being shown on large video screens so that they could be identified (Upadhyay 2013b; Chandramohan 2013b; BBC News India Staff 2013a; H. Kumar 2013a). By June 22, Kavita Upadhyay (2013b) reported that eighty-two thousand visitors had been safely evacuated from Uttarakhand but that over twenty thousand were still trapped in the Rudraprayag, Chamoli, and Uttarkashi districts. Also by June 22 the Railway Ministry had begun to run special trains for returning survivors to their homes.

Uttarakhandis themselves were realizing their losses, and in many places such as the Kedarnath valley were doing so amid electricity outages, roads blocked by landslides, interruptions in the arrival of goods from the plains, and a fog of uncertain and incomplete information about what was happening. Speaking on the phone with a friend who was in Ukhimath at this time was difficult: I imagined that I could feel something of the weight of the lack of electricity and diminished availability of fresh food combined with building grief and anxiety about the unfolding situation. At the same time my physical distance and safety from the situation made me feel almost dizzy. My friend said that people were spending a lot of time sitting inside and in the dark, full of grief and uncertainty, eating only staple foods like dal and roti. In May 2014 in Dehra Dun I spoke with an Uttarakhandi journalist who had journeyed via helicopter with the Indian Army and was one of the first civilians on the ground near Kedarnath. He spent four days walking between Chaumasi (north of Kalimath and southeast of Kedarnath), the remains of Rambara, and Tosi (above Triyugi Narayan to the southwest of Kedarnath), namely the area that at the time was filled with living, dead, and dying survivors of the floods. He gave food, assistance, and companionship where he could. "So much pain [Hindi: $d u k h$ ]," he said to me, sitting in an overpriced coffee in the Barista coffee shop in Dehra Dun. "We are lucky [Hindi: Ham bhagyashali hain]. We should live life [Hindi: Jina parta hai]."

Announcements about financial relief began to circulate as relief supplies (food, clothing, kerosene, medicine) began to flow into the mountains. News articles and 
still and video images began to circulate on television, radio, the Internet, and Facebook and among cell phone users, celebrating the efforts of Indian solders to deliver food to survivors who had not yet been rescued and to help people cross swollen rivers to safe evacuation points (A. Bhatt and Press Trust of India 2013; H. Kumar 2013b; A. Bhatt 2013).

The materiality of death began to force its way still further into the situation. By June 21, bodies were washing ashore in Haridwar, over two hundred kilometers south of Kedarnath, and Kedarnath survivors were recounting the numbers of dead they had passed on their way out of the valley (BBC News India Staff 2013a; Press Trust of India 2013d). Google had created a Person Finder for Uttarakhand. As the number of confirmed dead rose, it was realized that many of the deceased could not be moved from where they had been found, and there began to be public discussions and disagreements surrounding the issues involved with a mass cremation in Kedarnath (Press Trust of India 2013b). The cremation, a public health necessity, was eventually carried out in Kedarnath after several challenges were surmounted. This was an immensely painful issue that added to the shock of loss because relatives did not have access to the bodies of their deceased family members within the required amount of time and could not honor their ritual obligations to the dead. There were public disagreements about the appropriateness and timing of the cremations and how they would affect the purity of the temple. When I spoke about this with a friend of mine in Ukhimath by phone on July 3 , 2013, he said "He [Shiva] lives in the cremation ground, so what is the necessity?" (Hindi: Shamshan wala hai to kya zarurat?)

After being delayed by weather, the cremations began in Kedarnath on June 28. There were demonstrations in Dehra Dun where protesters demanded that the cremations not proceed (Bhaskar News Staff 2013). Protesters accused the state government of trying to cover up the true number of dead. I read about this online and heard about it in an e-mail from an incensed Garhwali friend at about the same time. He wanted me to write an exposé of what was happening. This was one of the first moments when I had to consider how my responsibilities were changing. I had become accustomed to resisting the push to publicly hymn the greatness of Kedarnath and say that I was writing a modern mahatmya, a hymn of glorification for the tirtha. At many moments during my fieldwork I spoke with someone who welcomed my presence because, it was proclaimed, I would return to America and undertake the promotion (Hindi: prachar) of Kedarnath. In most of these moments I would correct my interlocutor and say that my job as a researcher was not to do prachar but to write about reality (Hindi: hakikat) - what was really happening. This kind of statement made people nervous because in Kedarnath, as in any important place of religious and economic significance, there were gritty realities to how life was lived that did not fill locals with pride. I would explain that I did not intend my work to be an exposé that would focus only on the problems of the place but that I was attempting to give a full and truthful account. 
But in 2013 there was a different tone to such questions - a demand from friends that I take a public position of critique, with the subtext "Here is something you can do that might actually help the situation, unlike most of the things you do in Garhwal, which are not relevant for us here." I said that I had begun to write something but that my sort of writing took a bit more time and that I was tryingan unsatisfactory answer. Even then I also knew that what I was writing would probably not be fully satisfactory to my friend. Edward Simpson, both in the context of both his own ethnographic writing on the aftermath of the 2001 Gujarat earthquake and in relationship to larger questions about disaster and memory, has noted that disasters and their aftermaths sharpen the issues of position inherent in ethnographic writing. Public opposition to his own work raised for him significant questions about how ethnographers should respond or change their work process if those about whom they have written seriously disagree with their conclusions (Simpson 2016, 2014; Simpson and De Alwis 2008).

An additional ritual uncertainty of primarily local significance was playing out at this time: How and where would Shiva in his Kedarnath form be worshipped with the temple closed? I was often told during my fieldwork in 2006-8 that the designated pujari of Kedarnath takes a strict vow to remain continuously in Kedarnath for the duration of the season and to perform the worship of the rock linga of Shiva in the temple and the bhog murti (a small portable linga that usually resides in the residence of the pujari) twice daily without fail. The pujari of Kedarnath and his assistant from the Samiti are in effect the only two people who simply cannot leave in a normal season. The pujari in 2013 was Vageeshvar Ling. He had come to Uttarakhand as an adult, and until his posting to Ukhimath had been from Karnataka and living in Karnataka. He and I were on the same bus when I journeyed to Ukhimath to begin my fieldwork. Vageeshvar Ling, in the midst of everything, found and kept the bhog murti safe. On June 18 he performed its worship in Garud Chatti, two kilometers to the south of the temple. Within several days he was in Ukhimath, where traditionally the bhog murti is worshipped as Shiva in Kedarnath form when Kedarnath is closed for the season. In 2013 the winter worship of Kedarnath-Shiva began at the end of June. This move was criticized by a North India-based guru, Swami Swaroopanand, and others who said that the worship in Kedarnath should have been continuous (Zee Media Bureau 2013; Khandekar and Nagrath 2013).

This criticism had a particular resonance in the Kedarnath valley because, as in all of Garhwal and many other Himalayan regions, deity journeys and the conditions of their journey are immensely significant (Halperin 2012; Sax 1991; P. Sutherland 1998; Berti 2009). Once when I traveled with the doli to Kedarnath, I was told that several decades earlier the Samiti had tried to take the doli by bus part of the way and that the result had been terrible storms. If part of the reason this disaster happened was that locals had not been properly respecting the resident 
divine powers, what would the effects be of breaking yet another tradition? Viewed from another angle, of course, there was no choice. Kedarnath was uninhabitable. Another event could happen at any time. It could not serve as a place of worship until this impurity had been at least, in some way, nullified. The entire upper valley needed to be fumigated from the air (Hill Post Staff 2013). After my visit to Kedarnath in May of 2014, workers were still finding new corpses on the path to Kedarnath (Outlook India Staff 2014).

Uttarakhand quickly became, at the national and state levels, a marked arena for political contestation. On June 20 the then chief minister of Gujarat, Narendra Modi, wrote the central government railway minister asking that extra trains be made available free of charge to return Gujarati evacuees home (Dave 2013). On June 22, when his request to visit the Kedarnath valley was denied by the Congress Party-led state government, Narendra Modi visited Dehra Dun and "did an aerial survey" of some disaster-struck areas to protest the reply of Home Minister Sushilkumar Shinde that politicians not make visits to disasteraffected areas because doing so would use valuable resources (Hindustan Times Staff 2013; Press Trust of India 2013c). Yet at the same time Rahul Gandhi, one of the central figures of the Congress Party, was permitted to travel to Gauchar, a village in north-central Garhwal with an airfield that was serving as a staging ground for rescue and relief operations (Paljor 2013). By June 24 there were already numerous public critiques of how the state government was handling the situation, many of which focused on the person of Uttarakhand's chief minister, Vijay Bahuguna (Aron 2013; BBC News India Staff 2013b). On June 30 Bahuguna rejected Modi's offer that Gujarat would rebuild the Kedarnath temple (Press Trust of India 2013a). Congress Party-led Uttarakhand emphasized its connection to the central (then also Congress Party-led) government. Yet at the same time Modi found an efficient and symbolically powerful way to deliver disaster relief up into the mountains very early on, at a time when officially involved governmental organizations were having difficulties doing the same. Gujarat sent small, well-packaged packets containing a series of essential items for short-term survival (J. Bhatt 2013). A friend (who like many Hindus in Uttarakhand was a strong Modi supporter) said that in Ukhimath the arrival of these packets was an impressive bright spot amid the logistical chaos of broaderscale relief efforts. At the level of state politics, the aftermath of the floods was an opportunity for persistent critique of the in-power Congress Party by the Bharatiya Janata Party (BJP) with the clear agenda of overthrowing Congress in the next round of state legislative assembly elections in 2017. By June 25 it was announced that rescue operations in Kedarnath were finished (Press Trust of India 2013j). One of the first news videos from Kedarnath, in which ABP News interviewed a representative of the Badrinath-Kedarnath Temples Committee, showed that just a week later Shiva's Kedarnath form had already begun to 
receive worship again in the simple form of bilva leaves, all other ritual materials being unavailable (ABP News 2013).

One of my main sources of information as events were unfolding was Facebook, particularly the Facebook networks of Garhwalis connected in some way or other to the Kedarnath valley. I saw cell phone and news videos (literally thousands of which were available on YouTube) of unfolding rescue scenes: soldiers carrying people up and down hills, helping people climb out of vehicles that had fallen off the road, feeding people, in some instances creating bridges with their own bodies. I saw many pictures of destroyed and submerged houses and roads. Many of these images were shot by someone from the area for viewing by other people from the area. I saw people trying to find out through Facebook whether a relative or friend had survived. One thread I viewed was written on June 19 by someone relaying (and translating from Garhwali to Hindi) and coordinating an appeal for help. The writer had a dying but partially functional cell phone and was trapped above Sonprayag with a group of about twenty people, several of whom were in bad shape and were not able to contact rescue personnel themselves. Digital photos of news articles were shared and reshared, many without searchable titles. Again and again in Facebook postings in these early weeks I also observed the anger of Garhwalis at the bad reputation (Hindi: badnam) being created by exploitative treatment of yatris and embarrassment that some of what was reported in the news might actually be occurring; in counterpoint, multiple postings stressed locals' generous and heroic behavior (Hindu Staff 2013b). In those first weeks yatris were getting most of the attention, and locals noticed. Here is an example of morbid humor (translated from the Hindi) that was posted around this time on the Facebook page of a friend of mine. It contrasts what the situation on the ground looks like to a reporter from a news channel compared to how it looks to a Garhwali:

News Channel: Look how the soldiers are carrying people up these rocky paths on their backs.

Garhwali: Brother, whenever anyone gets sick we carry them to the hospital like that.

News Channel: Look at how yatris are saving their lives by traveling on these twisting paths.... And they are saying we will never again come to such a place again.

Garhwali: Our children go to school on a thousand paths like this.

News Channel: The rain still has not stopped-going any further will be dangerous. Our team has stopped here.

Garhwali: Brother, if we waited for the rain to stop then we would never eat or drink, our children would not go to school, ... our women would not go to work, our families would die hungry.

News Channel: The road is broken here. ... When the Indo-Tibetan Border Force comes they will repair it. 
Garhwali: Listen, younger brother, go get a shovel and a spade. The water is going to the wrong place. We will make a canal for the water and this will fix the road.

News Channel: Look at how our cameramen and reporter have come by a difficult road and through cascading waters.

Garhwali: Brother, on a day like this we have to cross cascading waters like this ten times a day.... Our barn is over in this direction....

News Channel: We have had with us for four days a local laborer-let's talk to him. "Are you connected to anyone who is trapped here and who assigned you here? Is the government paying you?"

Employee: Sir, my name is Shishupal, and I am a commando in the Indian Army, enlisted in the Second Parachute Regiment. Just now I was on a vacation, and my home is here in Ukhimath. This tragedy has happened here so I know everyone involved; my uncle is trapped in Kedarnath, and I have come here to help him and find out his condition. This is my brother Shankar. He is a software engineer in Delhi; and is here now also on a vacation, and since the tragedy he has extended his vacation for seven days.

News Channel: For some reason we will not be able to tell you the condition of the local worker [Shishupal] but we can tell you that the Bahuguna administration is doing good work and that local workers are working alongside the army.

For locals, monsoon season in the mountains is not, for many, something from which there can be a rescue. Unless one moves down from the mountains and leaves Garhwal behind, mountain living in the best of circumstances is irreducibly hard. Further, in many cases local residents know their environment the best and are able to make the most useful interventions in the landscape. This point, discussed further in the next chapter, constitutes a refrain in literature about disaster prevention, disaster recovery, and sustainable development. And these facts of pahari life were constantly elided in the dramatic news pieces that showed people being heroically "rescued" by civilians, soldiers, relief workers, and other government personnel.

Imagine, then, how the early summer of 2013 felt to people in the Kedarnath valley. They were stuck in the middle of a heavy monsoon. Each day brought the threat of more landslides. People were in the first stages of dealing with great loss and in many cases were doing so without access to the bodies of their dead. They had ritual obligations that they could not fulfill properly. It was uncertain how much help was going to come from the government. Guptkashi (and to lesser extent Ukhimath, because of its location on the other side of the valley) was swarmed by survivors, relief supplies, nongovernmental organization (NGO) workers, journalists, and government officials. The state and central governments had begun financial assistance, compensation, and loan deferral for disaster-affected 
individuals and families but in an uneven way. There were numerous, conflicting announcements being made about the nature and time frame of reconstruction. There was no as yet universally agreed-upon explanation of the underlying causes of the disaster. And who knew if more was yet to come? It was still raining; there were still landslides.

If I force my mind away from the Kedarnath valley and think about the situation from the point of view of visitors to the region, it seems to me that the floods were, among other things, a complete betrayal of expectation about the nature of travel in the Himalaya at the beginning of the twenty-first century. When I spoke with people visiting Kedarnath in 2007 and 2008 about what they felt while present in Kedarnath, the answer would often include the words peace (Hindi: shanti) and/ or satisfaction (Hindi: santushti). Some reported experiencing shanti because by virtue of being in a place like Kedarnath they had left all the worries of their daily lives behind (this was a very common sentiment), and santushti because they had successfully arrived in Kedarnath and by doing so had affirmed their connection to the older layers of Hindu traditions of which yatra was an important emblem. Added to this was the fact that in recent years travel in the Uttarakhand Himalaya, while still arduous and risky, had become increasingly comfortable-an attractive yatra destination for a family looking to get away from the heat of the plains, make a meaningful journey, and experience the famous "natural beauty" of the Himalaya, often while balancing the comforts of higher-end lodging with the mild arduousness of travel in the mountains. Thus the disaster was a profound betrayal, a shocking reversal of what a Himalayan yatra in the twenty-first century was supposed to be, the opposite of the feeling of rest, accomplishment, reconnection with tradition, and closeness to divinity/nature. For paharis it was a betrayal of a different kind, detailed in the next chapter.

\section{REOPENING}

Confusion swirled around the question of when the temple would reopen, who would be involved, and what would be revealed about the health of the physical structure itself. The Indian Army began work on a new footpath to Kedarnath from near Sonprayag. Building on the wisdom of most of the older travel routes in the valley, it would stick to ridgelines and avoid moving along the landslide-prone sides of the Mandakini River valley (Press Trust of India 2013h). Just months after officials had announced that it would be one if not several years before Kedarnath reopened, it was announced that Kedarnath would reopen on September 11, 2013 (Press Trust of India 2013e). Peer-reviewed work by scientists specializing in Himalayan geology and glaciology had also become a greater part of the public conversation about what had happened in Kedarnath. There had been numerous interviews and blogs on the topic beginning almost immediately after the floods (Bagla 2013; Mihir and Irani 2013; Petley 2013). But it took a bit more time for 
scientists, now working under a new kind of pressure and sense of responsibility for producing work that would enter public conversation, to offer preliminary analyses aimed at fellow scientists (Dobhal et al. 2013). The situation began to feel more of the weight of scientific modes of discourse and authority.

Kedarnath and the upper Kedarnath valley continued to feel like a place where human efforts were both going wrong and persistently attempted again and again, yet the pressure was on to rebuild Kedarnath so that the site could reopen as quickly as possible. The Rudraprayag-Guptkashi road closed several times because of landslides. Yet in the same month the Indian Ministry of Road Transport and Highways said that they planned to restore road connectivity to Kedarnath by the end of September (Press Trust of India 2013g). The Nehru Institute of Mountaineering recommended the development of an alternate route to Kedarnath from the east via Kalimath and Chaumasi (Gusain 2013b). Numerous NGOs were working with specific village populations (Dundoo 2013; Disaster Mitigation and Management Centre, 2015).

The BJP criticized the reopening of the temple on the grounds that it was a ploy to divert attention from state government mismanagement and that the association of Kedarnath pilgrimage priests had not been consulted (Chandramohan 2013a). Archaeological Survey of India and Geological Survey of India teams began mapping projects aimed at assessing the extent of the damage to the built environment and the broader geological situation. The opening precipitated a new round of survivor accounts and reviews of recent events in the media. The ritual dynamics of this time were fluid and confusing, a blend of the hopeful and the disturbing. Official worship of Shiva in Kedarnath began with a havan and anusthan performed by the Rawal Bheemashankar Ling that was attended by representatives of the Badri Kedar Samiti, the association of Kedarnath pilgrimage priests, and prominent state politicians. Significantly, weather prevented Vijay Bahuguna from attending as scheduled. Part of the work of this ritual was, in a ritual sense, a work of repurification. But this was a poignant repurification, as those present in Kedarnath continued to find new corpses as they removed layers of mud and debris from the ruins of the village. Locals were finding bodies as they excavated their shops and guesthouses. At some level, as Shashank Srivastava has suggested, these rituals of place and worship were aimed at selfrepurification rather than repurification of place and temple. ${ }^{5}$ On September 21 it was reported that the Archaeological Survey of India had announced that the ghee from the ghee malish, one of the distinctive features of a visit to Kedarnath in recent memory, had begun to rot and was preventing the stone from breathing naturally. According to India Today, this pronouncement produced a surprising response from the Samiti that avoided commenting directly on the ghee malish of the linga and instead focused on the walls of the inner sanctum: "Smearing the walls with ghee is a practice with no religious significance" (Gusain 2013a; Y. Kumar 2014). 
On October 4, the first day of fall Navaratri, Kedarnath opened for yatris. This had traditionally been a time when Kedarnath saw many Bengali visitors. In 2013, the special connection between West Bengalis and the Himalaya was honored in a different way: Durga Puja celebrations in West Bengal saw the construction of many floats and displays depicting the Kedarnath temple. Actually reaching Kedarnath was difficult at this time. Worries about weather and landslides persisted, and even getting into the mountains felt like a gamble to visitors. Many places on the road between Rudraprayag and Sonprayag were dangerous. The government began requiring registration of yatris in Guptkashi and Sonprayag. The arrival of thirty-four people in Kedarnath on a given day during this period was newsworthy (Amar Ujala Staff 2013b). The state was trying to show that Kedarnath and the Char Dham were open again for business, but it was a difficult message to sell. On October 29 Kavita Upadhyay (2013c) wrote that "since June 24th 2013, 545 bodies have been disposed of and cremated in the Kedarnath Valley both, as part of the combing operations and debris clean-up. Almost 50 percent of these bodies were recovered from Kedarnath itself."

The doors of the Kedarnath temple closed for the winter on November 5. Raghav Langar, the district magistrate for Rudraprayag, announced that further recovery of the dead in Kedarnath would have to wait until spring (Amar Ujala Staff 2013a). Hundreds of people believed to be in Kedarnath still had not been located (V. Singh 2013). On November 6, Brijesh Bhatt (2013) wrote that 1,600 yatris had taken darshan since the apda. According to Ushinor Majumdar (2013), the number was "nearly 1,400." To put this in perspective, around ten thousand visitors per day usually came through Kedarnath during the high season in some of the years leading up to 2013. The Kedarnath doli returned again to Ukhimath after the traditional closing puja that is known as samadhi puja. As with the September opening, the procession took a slightly different route, skirting Rambara and Gaurikund and sticking to the higher footpaths, the thoroughfares of earlier times.

In Badrinath, as in Kedarnath, there is a tradition that when the shrine is closed it is the turn of divine beings to come to the site on pilgrimage while it is off limits for humans. With Kedarnath-Shiva in samadhi for the winter, it began to sink in that there would be no returning to how things were. Official statistics were updated and reconfirmed. On December 7, Kavita Upadhyay (2013a) wrote that the Ukhimath administrative block (Hindi: tehsil) had experienced 584 deaths and that 296 women had been widowed. High-level Uttarakhand government employees tasked with disaster recovery visited Orissa to compare notes. In October of 2013 Orissa faced inland flooding caused by Cyclone Phailin. In notable comparison to Uttarakhand, there were relatively few deaths because the state forced people to leave their homes (Press Trust of India 2013k). In what had now become a familiar postdisaster political trope, Modi continued to criticize the 
Congress Party government in Uttarakhand. Worry over what would happen during the pilgrimage season of 2014 hung over the state. And it was a very frustrating worry because not much could be done on site or even beyond Gaurikund until the snows began to melt in the spring. But already Uttarakhandis were seeing that almost no yatris were booking rooms for the following season.

\section{MOVING FORWARD}

It has been observed that "disaster victims . . . tend to merge into an immediate unity that later fragments" (Hoffman and Oliver-Smith 1999, 7). This initial unity and later fragmentation were clearly evident in Kedarnath and in the Kedarnath valley, and the specific patterns warrant extended analysis. That is not, however, the focus I wish to emphasize here. Rather, I want to notice how the intersubjective unity of the immediate postdisaster moment nested inside the broader ways in which Kedarnath, as a Shaiva pilgrimage place in the Himalaya, generally creates and reflects shared experiences of the power of the place. That is to say, the disaster did not fundamentally question the commonly held idea and experience that Kedarnath is a place where a divine power is resident in and part of the place. Rather, it laid bare a destructive tangle of human relationships (with other humans, with divine powers, with the Himalayan landscape) that had, over time, become part of the complex eco-social system of Kedarnath.

In the first year after the floods, the Uttarakhand government found itself working at several different time scales all at once-trying to deal with immediate questions of relief, short-term questions about how the next year would unfold and how people would survive the coming months, and longer-term questions about what would be the new realities of the state. Journalists had written critically about the level of relief and rehabilitation the state had managed to provide by December (Majumdar 2013; Upadhyay 2013d; Press Trust of India 2013f). The tourism department had announced an array of initiatives aimed at both surviving the present and building the future: a new focus on adventure tourism that attempted to shift the tourist gaze away from the Char Dham, the regulation of the daily number of yatris in future seasons, the forgiveness or deferral of certain kinds of loans, and incentives for job retraining in the tourism sector (S. Sharma 2013; Majumdar 2013).

In the beginning of 2014, tensions between local groups, state, and center intensified, and confusion over how Kedarnath would actually be rebuilt deepened. The Geological Survey of India, an organ of the national government, stated in its initial report that nothing should be rebuilt in the immediate vicinity of the Kedarnath temple because of the instability of the area. They suggested (and pointedly referred to earlier reports where the same suggestion had been made) that the township be rebuilt slightly to the south and that the Mandakini River be 
rechanneled to its original preflood course. This immediately created an outcry in the Kedarnath valley community because local businessmen and particularly Kedarnath tirth purohits wanted their shops, guesthouses, and dharamshalas rebuilt (State Unit Uttarakhand 2016; Thapliyal et al. 2013; Gusain 2014b; S. Sharma 2014). Rahul Gandhi, a national public symbol of the Gandhian legacy in the Congress Party, met with the families of victims, and Uttarakhand chief minister Vijay Bahuguna urged Prime Minister Manmohan Singh to quickly supply national funds that could be used in road reconstruction (Press Trust of India 2014a; Jagran Post Staff 2014b). BJP criticism continued apace (Press Trust of India 2014c). Two days later, on January 31, 2014, Bahuguna resigned and was replaced by Harish Rawat, another senior figure in the Uttarakhand Congress Party who had narrowly missed becoming chief minister earlier (Press Trust of India 2014d). At almost the same time Uma Bharti, a highly visible member of the BJP at the national level, was placed in charge of the BJP unit in Uttarakhand (Jagran Post Staff 2014c). In the beginning of February the state received a massive loan of 1,200 crore (12 billion rupees) from the Asian Development Bank (Jagran Post Staff 2014a).

In one sense there were many encouraging signs - a change in leadership, massive infusions of funding, increased indications that the rebuilding of Uttarakhand would be a key issue between the BJP and the Congress Party at the national level. Harish Rawat immediately began working to reassure the public both inside and outside Uttarakhand that the state was on task (Upadhyay 2014b). He pointed out that much could be done under existing legislation without seeking new laws; designated the area between Rambara and Kedarnath as a "very special zone for rehabilitation and reconstruction"; said that there would be special safety apps for yatris and mobile health units stationed along the route; said that BSNL (the government communications company) would strengthen cell phone reception in the area; and promised that the route to Kedarnath and the Char Dham would be protected by round-the-clock weather satellite observation (Upadhyay 2014b; Jagran Post Staff 2014d, 2014e; Upadhyay 2014a; S. Joshi 2014b). On March 1 the state passed a resolution to compensate shopkeepers for inventory lost in 2013 , extending the benefits beyond the simple loss of life and property (Jagran Post Staff 2014f). On February 27, the day on which the festival of Mahashivratri fell in 2014, purohits in Ukhimath calculated that the Kedarnath temple would open on May 4.

There was equal cause, however, for worry. Almost as soon as plans were announced for the 2014 season, anxiety began to build about whether Kedarnath would be ready to open (Press Trust of India 2014b; Jagran Post Staff 2014d). In the months immediately after the flooding, many had said the site would take years to reopen. The problem was that the state economy did not have years. Uttarakhand could not afford to not be Dev Bhumi, home of the Char Dham, for an entire year. The tourist industry was already on high alert by February because advance book- 
ings for the upcoming season were almost nonexistent (J. Bhatt 2014). Not much could be done on the path between Gaurikund and Kedarnath until the snow began to melt (K. Singh 2014). In March, as would have been the case in any March, concerns were still being publicly voiced about the condition of the roads (S. Joshi 2014a). In the beginning of April new skeletons were found in Rambara, and Harish Rawat was not able to visit Kedarnath to assess progress because the weather was too dangerous for helicopter travel (V. Rautela 2014; Gusain 2014a; Kunwar 2014). Public voices were discouraging Char Dham Yatra booking (Vembu 2014). Reading these reports in Wisconsin, I did not know what to pack for my trip and decided to pack as if I would be camping in the snow in Kedarnath, which frightened me and made the trip feel like a foolish thing to do. I downplayed my fears to my family.

Uttarakhand was preparing for the opening of the season, and at the same time India was preparing for national elections. The reconstruction of Kedarnath and the rebuilding of Uttarakhand were an ongoing thread in the voices and thoughts of people all over the country. People who worked in the Kedarnath valley did not see any reason to make the investments they would normally make at the beginning of the season but for the most part were not finding workable alternatives. Rather, they were oscillating between anxiety and concern about what the state and central governments were going to do, grief for their losses, and a structural, collective depression that felt unsolvable. The state government needed to move as quickly as possible to rebuild and restore the hope and brand reputation of the state, but the complexity and severity of the terrain, weather, and logistics made this difficult. The new chief minister, Harish Rawat, was attempting to distinguish himself from his predecessor Vijay Bahuguna and to signal to Uttarakhandi publics that his administration would work in greater accordance with the ideals that had led to the establishment of the state (for example, he met with representatives from disaster-struck regions in Gairsain, the Chamoli district mountain town that many had thought should be the mountain capital of the new mountain-state of Uttarakhand/Uttaranchal). The state Congress Party knew that if the public was not satisfied with how Uttarakhand would rebound after 2013, and perhaps even if it was, after the state assembly elections in 2017 the state government might again find itself controlled by the BJP. The BJP would in fact go on to win a resounding victory in the 2017 state assembly elections. And beyond the drama of electoral politics, the government found itself needing to repair its relationship with its people and constructively reaffirm the pahari character of much of the new state. Hovering behind and underneath everything was the way that the landscape and the weather continued to push back and weaken human efforts. And the closer one came to Kedarnath, the more difficult and confusing everything became. This was the fraught situation into which I journeyed at the end of April 2014 when I traveled to Uttarakhand for the first time since the apda. 